\title{
THE VEGETATION OF THE GOLDEN GATE HIGHLANDS NATIONAL PARK
}

\author{
B. R. ROBERTS, \\ Department of Pasture Science, \\ University of the Orange Free State.
}

\section{Introduction}

The Golden Gate Highlands National Park was established by the National Parks Board in the early 1960's and consists of a number of farms in the high mountain region between the villages of Clarens and Kestell on the border between the Orange Free State and Lesotho. The entire Park constitutes the upper catchment of the Little Caledon River. The Park encompasses the steep mountainous catchment from the hihgest points of the watershed at Rhebokkop (9283) and Generaalskop (8969) to the riverbed at 5,600 ft. The eastern boundary of the Park forms the watershed between the Orange and Vaal river systems.

The massive buttresses, clefts and gorges of the Cave Sandstone formation provide scenic grandeur unique in South Africa. This striking formation is overlain by basaltic lava to a thickness of 3,000 ft., forming a steep upper catchment of fertile and well-grassed hills and vaileys. The geology of the area has been mapped and described in detail by Van Eeden (1937) and Visser (1955).

The climate of the Park becomes more temperate with altitude, the vegetation of the upper reaches displaying a definite temperate affinity. The average annual rainfall measured over a period of 45 years at Oldenburg is $845 \mathrm{~mm}$ (34 in.) (Weather Bureau, 1965), the greater proportion falling between the months of September and May. The average annual rainfall varies considerably within short distances in this region, being $716 \mathrm{~mm}$ at Clarens, $774 \mathrm{~mm}$ at Clifton and $987 \mathrm{~mm}$ at Caledonia, all of which are within 10 miles of Golden Gate. Winters are cold, with frost and snow of general occurrence from May to August. The growing season is thus short and adaptations of the vegetation to the long cold dormant season are everywhere in evidence in the higher-lying areas of the Park.

The entire basaltic region (see map) which includes all the area lying above $6,800 \mathrm{ft}$. has an unusually fertile soil. This soil type has been shown by Staples and Hudson (1938) to be amongst the most fertile in Southern Africa and supports a dense temperate grassland which completely stabilizes the steep slopes of the upper catchment as such against erosion. The Cave 
Sandstone on the other hand produces a shallow sandy soil of low fertility (Roberts, 1966b) that is more susceptible to erosion losses. Underlying the Cave Sandstone, the Red Beds consisting of reddish-brown mudstone, produce a structureless powdery soil which is exceptionally prone to erosion. The Red Beds vary from 200 to $400 \mathrm{ft}$. in thickness and their unstable soils combined with the steep natural inclination of their exposed faces result in a poor vegetation and serious erosion problem in certain low-lying areas. The close proximity of this geological region to the homesteads and arable lands of the original farms that constituted the Park resulted in their being overgrazed and depleted of much of their original vegetation, thus aggravating the problem of erosion.

\section{The Vegetation}

The present survey covers that portion of the Park falling within the original boundaries of the farms Melsetter, Wodehouse, Gladstone, Glen Reenen, Wilgenhof and Golden Gate, a total of 4,986 morgen.

All specimens were collected during the summer and were identified by the National Herbarium, Pretoria, where a complete set of duplicate specimens is lodged. The numbers quoted are the author's collecting numbers as recorded in the herbarium of the Department of Pasture Science, U.O.F.S.. Unnumbered species are Liebenberg's (1965).

Published botanical work on the Golden Gate region is limited to the writer's brief sketch (Roberts, 1966a), Acocks' (1952) list of species collected near Ficksburg, Markötter's (1930) compilation of Thode's plant collections between 1891 and 1914 at Witzieshoek and Phillips' (1917) extensive list of plants of the Leribe plateau in Lesotho. Also akin to the Golden Gate vegetation are the high lying regions of the Natal Drakensberg as described by Killick (1963) and Edwards (1967) and the Lesotho Highlands as reported by Staples and Hudson (1938). Limited collections have been made at Golden Gate by Liebenberg (1965), who also produced an historical sketch of the area with reference to the animal population of earlier times.

The present survey does not permit the compilation of a detailed vegetation map of the Park, but is intended to provide a list of the more abundant species present. While the vegetation may more correctly be classified according to standard botanical taxa, for the purpose of this preliminary report the plants have been grouped according to easily recognizable structural categories. In the absence of other botanical references and in view of the need for a useful guide for the layman, this simple layout including common names is used.

The general distribution of vegetation formations is clearly seen on the aerial photographs of the Park. Virtually the entire Park carries a grassland vegetation, with the exception of certain deep valleys, protected gorges and crevices in the Cave Sandstone, where Leucosidea Forest or mixed LeucosideaKiggelaria-Buddleia Forest dominates. With the exception of Leucosidea 
and Protea, which are apparently comparatively resistant to fire, trees and shrubs are limited to those areas where rocks and boulders afford them protection from fire. The abundance of bulbous plants (geophytes) indicates that fire has been a characteristic environmental factor since the earliest times (Bayer, 1955).

\section{(a) Trees and Shrubs}

The following woody plants are typical of the successionally advanced communities in sheltered situations:

Artemisia afra Jacq. (Wildeals) 3312

Asparagus africanus Lam. (Katbos) 3219

A. asparagoides (L.) Wight (Krulkransie) 3230

A. ramosissimus Bak. 3229

Buddleia corrugata (Benth.) Phill. (Sagewood) 3242

Canthium ciliatum (Klotzsch) Kuntze 3397

Clutea pulchella L. (Lightning Bush) 3223

Cussonia paniculata Eckl. \& Zeyh. (Cabbage Tree) 3405

Diospyros whyteana (Hiern.) F. White (Kraaibessie) 3398

D. austro-africana de Winter var. rubriflora (de Winter) de Winter 3456

Euclea coriacea A.DC (Berggwarrie) 3208

Halleria lucida L. (Tree Fuschia) 3396

Kiggelaria africana L. (Kershout) 3266

Lasiosiphon burchellii Meisn. 3205

Leucosidea sericea Eckl. \& Zeyh. (Ouhout) 3445

Maytenus undata (Thunb.) Blakelock (Koko Tree) 3264

Myrsine africana L. (Cape Myrtle) 3238

Printzia pyrifolia Less. 3380

Protea rouppelliae Meisn. (Suikerbos) 3394

Rhus dentata Thunb. (Nanabessie) 3231

R. discolor E. Mey. 3057

R. divaricata Eckl. \& Zeyh. (Kliptaaibos) 3326

R. pyroides Burch. (Taaibos) 3089

Rubus ludwigii Eckl. \& Zeyh. (Bramble) 3391

$R$. rigidus $\mathrm{Sm}$.

\section{(b) Plants with temperate affinities}

The increasingly temperate affinities of the vegetation with increase in altitude is a phenomenon which has been reported by many writers in South Africa (Acocks, 1963; Killick, 1963; Edwards, 1967 and Roberts, 1963a and 1966) and there is little doubt that in the absence of veld burning fynbos (macchial would increase and even dominate in many of the higher lying regions. The following woody temperate species are typical of the high altitude fynbos communities:

Anthospermum tricostatum Sond. 3121

Cliffortia filicauloides H. Weim. 3441 
C. nitidula R.E. Fr. \& T.C.E. Fr. var. pilosa H. Weim. 3193

Erica woodii H. Bol. 3083

E. algida $\mathrm{H}$. Bol.

Erica sp. 3279

Nestlera acerosa (DC.) Harv. (Perdeboegoe) 3404

Passerina montana Thod. (Bakkerbos) 3359

Petalactella woodii N.E. Br. 3337

Stoebe vulgaris Levyns (Slangbos) 3031

These plants are associated with a wide variety of temperate herbs and grasses representing genera typical of the winter rainfall region of the western Cape, eg. Helichrysum, Polygala, Senecio, Bromus, Pentaschistis, Festuca and Ehrharta.

\section{(c) Legumes}

Leguminous plants that occur in the Park are largely low-growing species but include a number of woody subshrubs such as Dichilus and Melolobium. Wild clover (Trifolium) is very abundant on the upper slopes of Generaalskop (8,969 ft.). The following legumes have been recorded, occurring mainly as grassland herbs:

Argyrolobium tuberosum Eckl. \& Zeyh. 3448

A. variopile N.E. Br. 3298

Calpurnia intrusa E. Mey. 3352

Cassia tomentosa Lam.

Dichilus strictus E. Mey. 3175

Dolichos linearis E. Mey.

Indigofera hedyantha Eckl. \& Zeyh. (Aambeibossie) 3113

I. rostrata $\mathrm{H}$. Bol.

I. tristis E. Mey. 3362

I. tristoides N.E. Br.

Lessertia sp. cf. L. capitata E. Mey. (Kleingansies) 3068

L. sp. cf. L. pauciflora Harv. 3212

L. perennans DC. (Blaasertiie) 3225

Lotononis cytisoides Benth. 3123

L. lanceolata Benth.

L. laxa Eckl. \& Zeyh. 3349

L. magnistipulata Duemmer. 3110

L. procumbens $\mathrm{H}$. Bol.

L. woodii $\mathrm{H}$. Bol.

L. sp. 3072

L. sp. 3174

Melolobium microphyllum Eckl. \& Zeyh. (Heuningbos) 3088

Tephrosia capensis Pers.

Trifolium africanum Ser. (Wild clover) 3122

Rhynchosia caribaea DC.

R. totta DC. 
In addition to the above, Markötter (1930 records the following genera in the nearby Witzieshoek area: Dumasia, Elephantorrhiza, Eriosema, Pleiospora $(=$ Phaenohoffmania $O$. Kuntzel.

\section{(d) Succulents}

Succulent plants are poorly represented in the Park, as is typical of most high rainfall regions. The only genus which is relatively common is Crassula of which eight species have been collected. Further study will no doubt reveal more succulents, many of which are inconspicuous. The following have been recorded:

Aloe ecklonis Salm-Dyck (Grass aloe) 3446

Crassula compacta Schonl. 3382

C. anomala Schonl. \& Bak. f.

C. harveyi Schonl. 3059

C. muscosa L. 3202

C. natalensis Schonl. 3357

C. rubicunda E. Mey. 3442

C. setulosa Harv. 3145

C. sarcocaulis Eckl. \& Zeyh. 3341

Cotyledon orbiculata L. 3422

Delosperma sp. 3435

D. sutherlandii (Hook. f.) N.E. Br.

Euphorbia clavarioides Boiss 3427

E. striata Thunb. (Melkgras) 3036

Ruschia sp.

\section{(e) Bulbs}

The Liliaceae, Iridaceae and Amaryllidaceae are abundant in all areas of the Park and include a variety of striking wild flowers such as Agapanthus, Dierama, Gladiolus, Kniphofia, Watsonia and Zantedeschia. Most of the bulbous plants occur as grassland geophytes while a few such as Agapanthus are limited to rocky situations and Zantedeschia is a streambank lily. The following bulbous species were collected in flower during mid-summer, many of which are described and illustrated by Eliovson (1960):

Agapanthus campanulatus Leighton (Agapanthus) 3098

Albuca trichophylla Bak. (Slangkop) 3137

Aristea woodii N.E. Br. 3139

A. cognata N.E. Br.

Bulbine caespitosa Bak. 3184

B. abyssinica A. Rich.

Dierama igneum Klatt (Dierama)

3379

D. robustum N.E. Br. 3120

Drimia neriniformis Bak. 3204

Eucomis bicolor Bak. (Pineapple flower) 3434 
Galtonia candicans Decne (Berg lily) 3447

Gladiolus crassifolius Bak. 3119

G. dracocephalus Hook. f. 3393

G. edulis Burch. (Small Afrikaner) 3081

G. papilio Hook. f. 3029

Holothrix scopularia Reichb. f. 3173

Hypoxis costata Bak. (Kaffertulp) 3071

H. sp. 3101

H. sp. 3450

H. sp. 3026

Kniphofia triangularis Kunth (Red hot poker) 3387

K. sp. nov. (= Bruce's K. basutica Nat. Herb.) 3430

Moraea pubiflora N.E. Br.

Schizocarphus nervosus (Burch.) v.d. Merwe 3118

Scilla sandersonii Bak. (Brandui) 3271

Trachyandra asperata Kunth (Wildeknoflok) 3182

Tritonia? sp. 3034

Vellozia viscosa Bak. 3218

Watsonia densiflora Bak. 3048

Zanthedeschia oculata (Lindl.) Engl. (Arum lily) 3146

Markötter records six species of Kniphofia and seven species of Gladiolus from Witzieshoek.

\section{(f) Sedges and Rushes}

Members of the Cyperaceae and Juncaceae are typical of wet soils and are common constituents of streambank vegetation. Further study of these habitats should reveal a greater variety of sedges than the present list:

Bulbostylis collina (Kunth) C.B. C1. 3010

B. trichobasis (Bak.) C.B. Cl. 3214

Cyperus obtusiflorus Vahl. var. flavissimus Boeck. 3214

C. rigidifolius Steud. 3140

C. schlechteri C.B. Cl. 3096

C. semitrifidus Schrad. 3039

Fuirena gracilis Kunth 3250

Juncus exsertus Buch. 3345

Mariscus congestus C.B. Cl. 3181

Pycreus macranthus C.B. Cl. 3180

Restio sieberi Kunth (Besemriet) 3389

Scleria woodii C.B. Cl. 3087

Scirpus diabolicus Steud. 3295

\section{(g) Grasses}

The 51 species of Gramineae collected in the Park include representatives of both the temperate and subtropical floras. Most of the grasses 
are typical montane species e.g. Bromus, Festuca and Danthonia while others are distinctly hygrophyllous types e.g. Miscanthidium, Pennisetum and Paspalum. Hyparrhenia, Cynodon, Rhynchelytrum and Heteropogon are typical of the less exposed lower-lying habitats. The following grasses were recorded:

Agrostis barbuligera Stapf. var. longipilosa Goossens \& Papendorf 3280 A. bergiana Trin. 3253

A. lachnantha Nees (Bentgrass) 3178

Alloteropsis semialata (R. Br.) Hitchc. (Blackseed) 3051

Andropogon appendiculatus Nees (Bluegrass) 3168

A. filifolius (Nees) Steud. (Tweevinger) 3062

Anthoxanthum ecklonii (Nees) Stapf. (Sweet vernal)

3297

Aristida junciformis Trin. \& Rupr. (N'gongoni) 3043

Brachypodium bolusii Stapf (False brome) 3065

B. flexum Nees 3332

Bromus speciosus Nees (Purple brome) 3166

Catalepis gracilis Stapf \& Stent 3133

Cymbopogon plurinodis Stapf ex Burtt Davy (Turpentine grass) 3165 Cynodon hirsutus Stent (Fynkweek) 3316

Danthonia disticha Nees (Suurpol) 3156

D. drakensbergensis Schweick. (Besemgras) 3388

D. purpurea (Thunb.) Beauv. (Haasgras) 3171

D. stereophylla J. G. Anderson 3152

D. stricta (Nees) Schrad. (Bokbaard) 3282

Digitaria flaccida Stapf (Kruisgras) 3014

D. monodactyla (Nees) Stapf (Eenvingergras) 3013

D. sp. cf. D. pentzii Stent 3074

Ehrharta erecta Lam. 3236

Elyonurus argenteus Nees (Koperdraad) 3017

Eragrostis capensis (Thunb.) Trin. (Hartiiesgras) 3047

E. chloromelas Steud. (Krulhaargras) 3015

E. plana Nees (Taaipol) 3052

E. racemosa (Thunb.) Steud. 3049

Festuca caprina Nees (Bokbaardgras) 3365

Fingerhuthia sesleriaeformis Nees (Thimble grass) 3158

Harpechloa falx (L.f.) Kuntze (Caterpillar grass) 3042

Helictotrichon capense Schweick. 3179

H. hirtulum (Steud.) 3222

H. longifolium (Nees) Schweick. (Brandgras) 3169

H. turgidulum (Stapf) Schweick. (Oatsgrass) 3044

Heteropogon contortus (L.) Beauv. (Speargrass) 3053

Hyparrhenia hirta (L.) Stapf (Thatchgrass) 3155

Koeleria cristata (L.) Pers. (crested koeleria) 3063

Melica racemosa Thunb. (Haakgras) 3428

Microchloa caffra Nees (Elsgras) 3340

Miscanthidium erectum Stent \& C. E. Hubbard (Tamboekie) 3164 
Paspalum dilatatum Poir. (Paspalum) 3064

Pennisetum sphacelatum (Nees) Dur. \& Schinz 3066

Pentaschistis setifolia (Thunb.) McClean 3157

Rendlia altera (Rendle) Chiov. (Kleinrolblaar) 3281

Rhynchelytrum setifolium (Stapf) Chiov. (Redtop) 3162

Sporobolus centrifugus Nees 3019

Stiburus alopecuroides (Hack.) Stapf (Pongwa) 3016

Themeda triandra Forsk. (Redgrass) 3060

Trachypogon spicatus (L.f.) Kuntze 3161

Tristachya hispida (L.f.) K. Schum. (Rooisaad) 3054

(h) Herbs and Subshrubs

A heterogeneous list of 148 herbs and small bushes which cannot be conveniently grouped with the other categories of plants has been recorded. The most well represented genera in this group are Helichrysum $(20 \mathrm{spp}$. ), Senecio (12 spp.), Sutera (4 spp.) and Zaluzianskya (4 spp.). Many of this group are showy wild flowers, e.g. Ajuga, Clematis, Harveya, Helichrysum, Selago, Streptocarpus and Walafrida. The following plants were collected in flower in January:

Alepidea amatymbica Eckl. \& Zeyh. (Kafferkalmoes) 3372

A. setifera N.E. Br. 3377

A. longifolia E. Mey subsp. angusta (Duemm.) Weim. 3210

Ajuga ophrydis Burch. ex Benth. 3058

Anthospermum rigidum Eckl. \& Zeyh. 3024

A. herbaceum L.f.

Aristea cognata N.E. Br. 3402

Asclepias fruticosa L.

A. sp. 3347

A. sp. 3189

Aspidoglossum interruptum (E. Mey.) Bullock

Aster muricatus Less. (Bloublommetjie) 3141

A. filifolius Vent.

A. petiolatus Harv. (Bergbloubos) 3286

Athrixia angustissima DC. 3207

Barleria monticola Oberm. 3215

Berkheya purpurea (DC.) Mast. (Bloudisseldoring) 3203

B. cirsiifolia (DC.) Roessl.

B. montana Wood \& Evans

B. rosulata Roessl. 3112

B. rhapontica (DC.) Hutch. \& Burtt Davy

B. spesiosa (DC.) O. Hoffm. subsp. lanceolata Roessl.

(Skraaldisseldoring) 3243

Cenia microglossa DC. 4246

Cerastium arabidis E. Mey. ex Fenzl emend. Moeschl. 3075

Chrysocoma tenuifolia Berg. (Bitterbos) 3426 
Cineraria aspera Thunb. (Geelkransbessie) 3400

C. lobata L'Hérit. (var. multiloba M. R. F. Taylor) 3370

C. lyrata DC.

Cirsium vulgare (Savi) Ten. (Scotch thistle) 3437

Clematis brachiata Thunb. (Traveller's Joy) 3226

Commelina africana L. (Wandering Jew) 3030

Conyza pinnata (L.f.) Kuntze

C. podocephala DC.

Corycium nigrescens Sond.

Cotula sp. cf. C. hispida (DC.) Harv. 3350

Cycnium racemosum Benth. 3077

Cynoglossum hispidum Thunb. (Beestongblaar) 3128

C. lanceolatum Forsk.

Cyphia elata Harv. var. (Baroe) 3115

C. elata Harv. var. stenophylla E. Wimm. (Baroe) 3094

Dianthus basuticus Burtt Davy (Bergangelier) 3200

Diascia integerrima E. Mey. ex Benth. 3274

Diclis reptans Benth. 3335

Euryops laxus (Harv.) Burtt Davy (Stinkharpuis) 3190

Galium capense Thunb. (Tiny-tots) 3114

G. rotundifolium L. 3221

G. wittebergense Sond.

G. subvillosum Sond.

Gazania krebsiana Less. subsp. krebsiana (Botterblom) 3440

Gerbera ambigua Sch. Bip.

Geranium incanum Burm. f. (Bergtee) 3330

Gnaphalium luteo-album L. (Roerkruid) 3339

G. undulatum L. (Groenbossie) 3354

Gunnera perpensa L. (Rivierpampoen) 3425

Haplocarpha scaposa Harv. (Bietou) 3209

Harveya coccinea Schltr. (Rooi-inkblom) 3129

Hebenstreitia integrifolia L. (Katstert) 3095

Helichrysum adenocarpum DC. (Rooisewejaartiie) 3272

H. appendiculatum (L.f.) Less. (Sewejaartiie) 3170

H. aureo-nitens Sch. Bip. (Griqua tea) 3040

H. chionosphaerum DC. 3090

H. dregeanum Sond. \& Harv. (Bergankerkaroo) 3117

H. aureum (Houtt.) Merrill (Geelsewejaartiie) 3344

H. hypoleucum Harv. 3291

H. miconiaefolium DC. (Kaffertee) 3328

H. nudifolium (L.) Less.

H. sp. cf. niveum (L.) Less. 3092

H. odoratissimum (L.) Less. (Hottentots kooigoed) 3278

$H$. oreophilum Klatt

H. rugulosum Less 3183

H. psilolepis Harv. 
H. scapiforme Moeser. 3293

H. setosum Harv. 3305

H. splendidum (Thunb.) Less. 3355

H. squamosum Thunb. 3401

H. sutherlandii Harv. 3358

H. undatum (Thunb.) Less. var. pallidum (DC.) Harv. 3079

Heliophila sp. 3303

H. sp. 3069

Hermannia betonicaefolia Eckl. \& Zeyh. (Asmabossie) 3196

H. coccocarpa Burtt Davy 3325

$H$. erodioides (Burch. ex DC.) Kuntze

Ipomoea sp. 3216

Lasiosiphon kraussii Meisn. (Gifbossie) 3033

Lepidium sp. (Peperbossie) 3324

Limeum viscosum (Gay) Fenzl. subsp. viscosum var. glomeratum (Eckl. \& Zeyh.)

Friedr. (Klosaarbossie) 3373

Linum thunbergii Eckl. \& Zeyh. 3322

Lithospermum vinereum DC. (Naelbossie) 3334

Lobelia filiformis Lam. var. krebsiana (Presl) E. Wimm. forma rusticana

E. Wimm. 3138

Manulea bellidifolia Benth. 3299

M. benthamiana Hiern 3361

M. thodeana Diels 3336

Mentha aquatica L. (Kruistement) 3292

M. longifolia Huds. var. capensis Briq. (Balderjan) 3307

Monopsis scabra (Thunb.) Urb. (Wild violet) 3056

Monsonia biflora DC. (Naaldebossie) 3086

Muraltia alticola Schltr. 3041

Myosotis sylvatica Hoffm. (Forget-me-not) 3233

Nemesia capensis (Thunb.) Kuntze (Leeubekkie) 3317

N. coerulea Hiern 3206

N. melissaefolia Benth. 3249

Nidorella resedifolia DC 3134

Nolletia ciliaris (DC.) Steetz 3021

Oenothera tetraptera Cav. (Aandblom) 3333

O. stricta Ledeb. (Evening primrose) 3436

Pelargonium alchemilloides (L.) Ait. (Wildemalva) 3109

P. luridum (Andr.) Sweet. 3038

P. saniculaefolium Willd. 3275

P. sidifolium (Thunb.) Knuth

Peucedanum connatum E. Mey (Basteranyswortel) 3356

Phacocapnos pruinosus (E. May) Benth. 3439

Pharnaceum detonsum Fenzl

Phytolacca heptandra Retz (Inkbessie) 3329

Plectranthus grallatus Briq. 3239

P. fruticosus L'Hérit. 
Polygala hispida Burch. 320i

P. hottentota Presl 3135

P. rehmannii Chod. 3032

Psammotropha mucronata (Thunb.) Fenzl var. marginata Adams. 3304

Ranunculus multifidus Forsk. (Botterblom) 3364

Rumex lanceolatus Thunb. (Tongblaar) 3331

Salvia stenophylla Burch. ex Benth.

Scabiosa columbaria L. (Scabious) 3027

Schitostephium crataegifolium (DC.) Fenzl (Bergkrui) 3187

Schizoglossum nitidum Schlecht. (Stinkmelkbos) 3150

S. pachyglossum Schltr.

S. stenoglossum Schltr. 3085

Sebaea sp. 3284

S. leiostyla Gilg. 3097

Selago galpinii Schltr. (Bergblouaarbossie) 3107

Senecio arabidifolius O. Hoffm. 3276

S. affinis DC.

S. burchellii DC. (Geelgifbossie) 3327

S. sp. cf. S. concolor DC. 3443

S. sp. cf. S. erubescens Ait. (= Mogg 849 Nat. Herb.) 3449

S. hastatus L.

S. harveianus MacOwan 3082

S. hieracioides DC. 3255

S. inornatus DC.

S. isatideus DC. (Blouvleibossie) 3300

S. othonnaeflorus DC. (Bietou) 3070

S. rhyncholaenus DC.

Silene burchellii Otth. (Geelgifbossie) 3321

S. capensis Otth. (Wilde tabak) 3288

Solanum nigrum L. (complex) (Nightshade) 3287

S. pseudocapsicum L.

S. retroflexum Dun. (Melkbossie) 3262

Sopubia cana Harv. 3020

Stachys dregeana Benth. 3103

Streptocarpus sp. (genus under revision) (Streptocarpus) 3429

Striga bilabiata (Thunb.) Kuntze

S. elegans Benth.

Sutera caerulea (L.f.) Hiern (Ruikbossie) 3078

S. aurantiaca (Burch.) Hiern

S. microphylla Hiern 3104

S. polelensis Hiern 3383

S. pristisepala Hiern 3144

Taraxacum officinale (Web) Wigg (Perdeblom) 3367

Thalictrum caffrum Eckl. \& Zeyh. 3289

Thesium imbricatum Thunb. (Grootswartstorm) 3116

T. macrogyne A. W. Hill 
T. sp. 3432

Turbina oblongata E. Mey. ex Choisy

Ursinia nana DC. 3195

U. saxatilis N.E. Br. 3386

Urtica lobulata E. Mey (Stinging nettle) 3269

Venidium arctotoides (L.f.) Less. (Botterblom) 3245

V. microcephalum DC. (Gousblom) 3132

Veronica anagallisaquatica L. 3309

Vernonia natalensis Sch. Bip. 3384

V. hirsuta (DC.) Sch. Bip.

Walafrida apiculata Rolfe (Bitteraarbossie) 3076

W. densiflora Rolfe 3008

W. sp. cf. nachtigali Rolfe (Geilsiekteopslag) 3130

Wahlenbergia undulata (L.f.) A.DC. 3323

W. zeyheri Buek ex Eckl. \& Zeyh.

Zaluzianskya alpestris Diels

Z. lychnidea Walp. (Drumsticks) 3050

Z. maritima Walp. 3313

Z. ovata Walp. 3366

\section{(i) Ferns and Lower Plants}

The Bryophyta have not been included in this study. The Pteridophyta are well represented and the following have been recorded:

Adiantum thalictroides Willd. (Maiden hair fern) 3258

Asplenium monanthes L. (Mother fern) 3237

A. trichomanes L. 3252

Cheilanthes hirta Sw. (Parsley fern) 3228

Cystopteris fragilis (L.) Bernh. (Brittle fern) 3227

Mohria caffrorum (L.) Desv. (Scented fern) 3125

Notholaena eckloniana Kuntze (Resurrection fern) 3127

Pellaea quadripinnata (Forsk.) Prantl 3148

Pleopeltis macrocarpa (Willd.) Kaulf.

Polystichum ammifolium (Poir.) C. Chr. 3235

Pteris cretica L. 3247

Selaginella dregei (Presl) Hiern 3257

Woodsia montevidensis (Spreng.) Hieron. var. burgessiana (Gerr. ex Hook. \& Bak.) Schelpe 3259

\section{DISCUSSION}

This study was undertaken with the object of gaining a better knowledge of the vegetation to act as a basis for recommendations concerning the suitability for grazing and carrying capacity of certain sections of the Park into which game have been introduced. The present study of vegetation of Golden Gate indicates that only certain sections of the Park are well suited to grazing by game on a large scale. However, the problems which 
arise in establishing a game reserve in a sourveld grazing region, which is subject to severe winter conditions, are obvious and require closer study, particularly in the absence of carnivorous species. Liebenberg (1964) cites the writings of Arbousset and Daumas (1842), the French missionaries who travelled through the Golden Gate area. These writers state that reedbuck, klipspringer, springbuck and eland were abundant in the Maluti mountains and increased in number from year to year without ever migrating. These buck were preyed upon by lion, hyaena and leopard. In the nearby Butha Buthe area large herds of springbuck and red hartbeest are reported by these writers. Steytler (1932), however, writing on the history of Harrismith, which lies some 50 miles north-east of Golden Gate, states that in the mid-nineteenth century the game migrated to the western Orange Free State in the summer and to the eastern Orange Free State in the autumn. In the winter they decended from the Orange Free State mountains into Natal. As a result of the large scale slaughter of game west of the Wilge River this portion of the province was termed "Riemland" after 1871. The vague and contradictory historical evidence on earlier game populations and migrations is difficult to interpret, but the writer has elsewhere (Roberts, 1965) postulated how natural fires, winter conditions, water supplies and palatability of the veld were probably nature's veld management agencies in maintaining both the game and plant populations.

Clearly a more detailed study of the productivity of the veld of the Park and the nutritive requirements of the grazing animals concerned is required if the ecosystem is to be stabilized in such a way that the beauty of the Park and the safety of this important catchment area is to be ensured.

\section{ACKNOWLEDGEMENT}

The author is grateful for financial assistance from the Department of Agricultural Technical Services and the National Parks Board of Trustees in this project. Assistance from Messers B. A. Bouwer, P. A. Henning and W. L. J. van Rensburg with field work and herbarium specimens is gratefully acknowledged, as is the co-operation of the staff of the Botanical Research Institute in identifying the specimens and checking the manuscript.

Much of the material was collected by Mr. L. C. C. Liebenberg.

\section{BIBLIOGRAPHY}

ACOCKS, J. P. H. 1952. Veld types of South Africa. Bot. Surv. S. Afr. 28. U. of S.A.

ARBOUSSET, T. \& DUMAS, F. 1842. Relation d'un Voyage d'Exploration nord-est de la colonie du Cap de Bonne Espérance.

BAYER, A. W. 1955. The ecology of grasslands: in Grasses and Pastures of South Africa. Johannesburg: C.N.A.

EDWARDS, D. 1967. A plant ecological survey of the Tugela River Basin, Natal. Bot. Surv. S. Afr. 36. Republic of S. Afr.

ELIOVSON, S. 1960. South African Wild Flowers for the Garden. Cape Town: Timmins. 
KILLICK, D. B. J. 1963. An account of the plant ecology of the Cathedral Peak areas of the Natal Drakensberg. Bot. Surv. S. Afr. 34. Republic of S. Afr.

LIEBENBERG, L. C. C. 1964. Die grotere soogdiere wat vroeër dae voorgekom het in die omgewing van die Golden Gate Hooglandpark. Koedoe 7:99.

National Parks Board, Pretoria.

MARKÖTTER, E. I. 1930. 'n Plantgeografiese skets en die Flora van Witzieshoek, O.V.S., Oliviershoekpas, Natal en Koolhoek, O.V.S. Ann. Univ. Stellenbosch 8, Series A.

PHILLIPS, C. P. 1917. A contribution to the Flora of the Leribe Plateau and environs. Ann. S. Afr. Mus. 16: 1-375.

ROBERTS, B. R. 1963a. A contribution to the ecology of Cathcart and environs with special reference to slope exposure and soil pH. J. S. Afr. Bot. 29: 153162.

1963b. Ondersoek in die Plantegroei van die Willem Pretoriuswildtuin met spesiale verwysing na veldbenutting. Koedoe 6:137-166.

1965. Veld Management - the conerstone of conservation. Leaflet No. 19, Dept. Agric. Tech. Serv., S. Afr.

1966a. Observations on the temperature affinities of the vegetation of Hangklip Mountain near Queenstown, C.P. J. S. Afr. Bot. 32: 243-260. $1966 \mathrm{~b}$. Conservation of the Vegetation of the Orange Free State. VIth A.E.T.A.T. Symposium, Uppsala.

1966c. The Ecology of Thaba'Nchu - a statistical study of vegetation/habitat relations. Ph.D. Thesis. Univ. Natal.

STAPLES, R, and HUDSON, W. K. 1938. An Ecological Survey of the mountain area of Basutoland. Herts., England: Garden City Press.

STEYTLER, 1932. Die geskiedenis van Harrismith.

VAN EEDEN, O. R. 1937. The Geology of the country around Bethlehem and Kestell. Geol. Surv. Mem. 33. Union of S.A.

VISSER, D. J. L. 1955. The Geology and Archeology of the Little Caledon River Valley. Geol. Surv. Mem. 47. U. of S.A.

WEATHER BUREAU 1965. Climate of South Africa, Part 9. W.B. 20, Department of Transport, Rep. of S. Afr. 